\title{
Authentic leadership and follower trust in the leader: The effect of precariousness
}

\begin{tabular}{|c|c|}
\hline \multicolumn{2}{|c|}{$\begin{array}{l}\text { Authors: } \\
\text { Deon J. Kleynhans } \\
\text { Marita M. Heyns }^{1,2} \\
\text { Marius W. Stander }^{1,3}\end{array}$} \\
\hline \multicolumn{2}{|c|}{$\begin{array}{l}\text { Affiliations: } \\
{ }^{1} \text { Optentia Research Focus } \\
\text { Area, Faculty of Humanities, } \\
\text { North-West University, } \\
\text { Vanderbijlpark, South Africa }\end{array}$} \\
\hline \multicolumn{2}{|c|}{$\begin{array}{l}{ }^{2} \text { Department of Human } \\
\text { Resource Management, } \\
\text { Faculty of Economic } \\
\text { Management Sciences, } \\
\text { North-West University, } \\
\text { Vanderbijlpark, South Africa }\end{array}$} \\
\hline \multicolumn{2}{|c|}{$\begin{array}{l}{ }^{3} \text { Department of Industrial } \\
\text { Psychology, Faculty of } \\
\text { Economic Management } \\
\text { Sciences, North-West } \\
\text { University, Vanderbijlpark, } \\
\text { South Africa }\end{array}$} \\
\hline \multicolumn{2}{|c|}{$\begin{array}{l}\text { Corresponding author: } \\
\text { Marita Heyns, } \\
\text { Marita.Heyns@nwu.ac.za }\end{array}$} \\
\hline \multicolumn{2}{|c|}{$\begin{array}{l}\text { Dates: } \\
\text { Received: } 10 \text { Apr. } 2021 \\
\text { Accepted: } 23 \text { Aug. } 2021 \\
\text { Published: } 27 \text { Oct. } 2021\end{array}$} \\
\hline \multicolumn{2}{|c|}{$\begin{array}{l}\text { How to cite this article: } \\
\text { Kleynhans, D.J., Heyns, M.M., } \\
\text { \& Stander, M.W. (2021). } \\
\text { Authentic leadership and } \\
\text { follower trust in the leader: } \\
\text { The effect of precariousness. } \\
\text { SA Journal of Industrial } \\
\text { Psychology/SA Tydskrif vir } \\
\text { Bedryfsielkunde, 47(0), } \\
\text { a1904. https://doi. } \\
\text { org/10.4102/sajip.v47i0.1904 }\end{array}$} \\
\hline \multicolumn{2}{|c|}{$\begin{array}{l}\text { Copyright: } \\
\text { (C) 2021. The Authors } \\
\text { Licensee: AOSIS. This } \\
\text { is licensed under the } \\
\text { Creative Commons } \\
\text { Attribution License. }\end{array}$} \\
\hline \multicolumn{2}{|l|}{ Read online: } \\
\hline 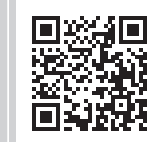 & $\begin{array}{l}\text { Scan this QR } \\
\text { code with your } \\
\text { smart phone or } \\
\text { mobile device } \\
\text { to read online. }\end{array}$ \\
\hline
\end{tabular}

Orientation: In a business context characterised by precariousness and uncertainty, the importance of trusting leader-follower relationships is becoming critical to navigate imminent challenges preventing organisational sustainability and progress. The potential negative impact of related challenges could be reduced by encouraging leaders to adopt an authentic leadership style, culminating in various positive employee and organisational outcomes.

Research purpose: This study investigated the impact of authentic leadership (AL) on follower trust in the leader (TL), while considering the possible indirect influence of perceived precariousness in the form of job insecurity.

Motivation for the study: Establishing a high level of trust among the followers and their leaders employed by a manufacturing organisation under operational and financial pressure might contribute to a more effective functioning of the entity.

Research approach/design and method: A quantitative cross-sectional survey design was applied. The Authentic Leadership Inventory, Workplace Trust Survey, and Job Insecurity Scale were administered.

Main findings: Authentic leadership was a significant predictor of TL. Job insecurity did not moderate the relationship between AL and TL.

Practical/managerial implications: Promoting an AL style will benefit manufacturing organisations as it will elevate the trustful relationship between leaders and followers, despite precarious working conditions.

Contribution/value-add: The study emphasises AL's critical role in cultivating a trustful relationship between followers and their leaders. The non-significant influence of job insecurity on a trustful relationship in a precarious work context was also highlighted.

Keywords: authentic leadership; trust; job insecurity; precariousness; organisational sustainability; mediation; moderation.

\section{Introduction}

The global economy has been affected by numerous economic crises over the past few decades, and this had had a negative influence on the world of work (Wang et al., 2021). The survival, advancement and competitiveness of organisations in the turbulent labour market depend on an organisation's ability to effectively manage the challenges brought about by change, both in the internal and external environment (Sartori \& Rolandi, 2013). Barrech, Baumert, Gündel, and Ladwig (2018) mentioned that optimisation and reorganisation initiatives to deal with challenges are becoming more frequent.

The South African economy has also been affected by challenges, one of which is the effects of the 2008 global financial crisis and subsequent weak growth. Constraints in electrical supply, reduction in the performance of industries such as manufacturing and an alarming unemployment rate of $30.8 \%$ also have had a negative impact on the economic performance of South Africa (Statistics South Africa 2020). To try and stay afloat in the competitive business environment, companies frequently implement cost reduction, reorganisation, or restructuring to remain competitive (Iverson \& Zatzick, 2011). Keim, Landis, Pierce, and Earnest (2014) stated that job insecurity as an element of precariousness is often one of the stressors that is synonymous with organisational change. Precariousness and related job insecurity have been linked to several health-related outcomes, such as diminished well-being and reduced self-rated health, which is detrimental to employees and employers (De Witte, Pienaar, \& De Cuyper, 2016). Breakwell 
(2020) posited that uncertainty can be linked to reduced trust between employees and employers. Karamat (2013) found that effective leadership is essential in ensuring organisational sustainability in the increasingly turbulent business environment. Therefore, leaders are responsible for creating an environment in which employees feel safe and secure with trust in their leaders. Megheirkouni and Megheirkouni (2020) maintained that it is becoming increasingly evident that 21st-century organisations need a new type of leader. As a result of the rapidly changing business world, resulting in reduced steadiness and uncertainty, authentic leaders might be able to contribute to a situation of stability (Ciftci, 2020). An authentic leadership (AL) approach is required, especially when considering ethical and other business misconduct in organisations worldwide (Copeland, 2016). One of the critical elements of effective leadership is the authentic treatment of team members (Kouzes \& Posner, 2007). When employees perceive their leaders to display AL characteristics by being open and truthful and involving them in decision-making, employees respond positively to their work, report higher engagement levels and increased trust in leadership (Wong, Spence Laschinger, \& Cummings, 2010). Additionally, to increase trust, authentic leaders can foster respect and credibility (Bamford, Wong, \& Laschinger, 2013).

Consistent with the Social Exchange Theory (Blau, 1964), authentic leaders could impact the development and maintenance of exchange relationships with followers (Wang, Sui, Luthans, Wang, \& Wu, 2014). The authentic leader's trustworthiness, respectability, and integrity can be represented by the combined components of self-awareness, internalised moral perspective, and relational transparency, balanced processing (Ilies, Morgeson, \& Nahrgang, 2005). Avolio, Luthans, and Walumbwa (2004) put forth that these characteristics represent the critical attributes of a highquality social exchange relationship. It is thus possible to argue that through their behaviour, authentic leaders will increase the level of trust that their team have in them, thereby establishing a cooperative relationship between them and their followers to the benefit of the organisation.

Trust is known to be sensitive to context (Burke, Sims, Lazzara, \& Salas, 2007), such as one characterised by high volatility, which may cause trusting parties to become more risk-averse and hence less willing to extend trust towards others. Ruiz, Vives, Martínez-Solanas, Julià, and Benach (2017) believed that the changes in the business environment, labour market, and organisations have increased precariousness and employee insecurity, and have become part of a severe problem that might threaten employee and business wellbeing. When employees face uncertainty, they might feel vulnerable, placing an additional burden on the type of leadership style required to maintain trust in their leader.

\section{Research purpose and objectives}

This study aimed to investigate the relationship between AL and trust in the leader (TL) within a precarious business context in South Africa. Moreover, we wanted to determine whether the perceptions of precariousness (in the form of job insecurity) would possibly moderate the relationship between AL and TL.

Although the relationship between AL and TL has been investigated and confirmed by various studies over the years (Agote, Aramburu, \& Lines, 2016; Baker, 2020), limited studies are available that describe the relationship between $\mathrm{AL}, \mathrm{TL}$ and the influence of job insecurity within a precarious business environment in South Africa. Although previous research has found a relationship between AL and trust, the direct moderating role of precariousness has not, to the best of our knowledge, been investigated.

The theoretical contribution made by this study deepens knowledge and understanding of the nature of the relationship between AL, TL, and perceived job insecurity as an element of work-related precariousness. Firstly, this study makes a new contribution to the existing leadership literature by depicting the relationships among constructs within a model, which, to the best of our knowledge, has not been researched before. Secondly, the study contributes to the limited research on AL within extreme uncertain and volatile business settings. Thirdly, this study contributes to the existing literature by testing the constructs in a developing country context within a real-time situation. The contribution is brought about by illustrating that AL may strengthen TL and adaptability to challenging employment conditions.

\section{Literature review}

\section{Authentic leadership}

Luthans and Avolio (2003) explained that AL developed as an important research area in positive psychology. Authentic leaders are defined as individuals who are:

$[D]$ eeply aware of how they think and behave and are perceived by others as being aware of their own and others' values/moral perspectives, knowledge and strengths; aware of the context in which they operate; and who are confident, hopeful, optimistic, resilient, and of high moral character. (Avolio et al., 2004, p. 4)

Authentic leadership in organisations is described by Luthans and Avolio (2003):

$[A] \mathrm{s}$ a process that draws from both positive psychological capacities and a highly developed organisational context, which results in both greater self-awareness and self-regulated positive behaviours on the part of leaders and associates, fostering positive self-development. (p. 243)

Authentic leadership consists of four dimensions: the leader's relational transparency, internalised moral perspective, balanced processing and self-awareness (Gardner, Avolio, Luthans, May, \& Walumbwa, 2005). Knowing one's strengths and weaknesses and the social influence thereof on other individuals apply to self-awareness (Kernis, 2003). Balanced processing relates to a leader's ability to be unbiased when considering all available information before reaching a final decision (Leroy, Palanski, \& Simons, 2012). An internalised moral perspective would influence a leader to act with selfregulation and self-determination rather than to react to 
situational pressures (Avolio, Walumbwa, \& Weber, 2009). Relational transparency points to the leader's behaviour that demonstrates their authenticity and genuine feelings towards team members (Wei, Li, Zhang, \& Liu, 2018). Exhibiting relational transparency encourages mutual trust in organisations (Wei et al., 2018). In support of this view, several studies found a positive relationship between AL and TLs (Clapp-Smith, Vogelgesang, \& Avey, 2009; Maximo, Stander, \& Coxen, 2019; Wong et al., 2010).

\section{Trust in leader}

Trust can be defined as an expectation that one individual can rely on another individual's deeds and promises and that the individual intends to be true to their word (Bligh, 2017). The actions and character of a leader impact the willingness of an employee to trust the leader (Heyns \& Rothmann, 2015). In the context of social exchange theory, trust represents an acceptance of risk and uncertainty that the exchange partner may or may not reciprocate the expected behaviour (Whitener, Brodt, Korsgaard, \& Werner, 1998). When team members observe open communication, support and cooperation, willingness to sacrifice, confidence, predictability, and fair treatment in their leader's behaviour, it will enhance trust within the leader-follower relationship (Clapp-Smith et al., 2009). Trust in the leader is defined as the willingness of employees to be vulnerable to their leader's conduct, which is beyond the employees' control (Sendjaya \& Pekerti, 2010). Although an employee demonstrates the willingness to be vulnerable to the actions and decisions of a leader, there are no guarantees that the outcomes of the trust relationship will favour the employee.

Immediate supervisors who treat their team members fairly and take their needs into consideration when making decisions may enhance employee trust in them (James, 2011). Trust in a leader plays an essential role in inspiring employees to exert greater effort and perform beyond expectations (Schaubroeck, Peng, \& Hannah, 2013). Conversely, when leaders are perceived to be untrustworthy by their followers, these followers might spend more time protecting themselves, which can negatively influence their performance (Mayer \& Gavin, 2005).

Trust in the leader plays an integral part in the successful implementation of change initiatives within an organisation as it is deemed necessary for getting individuals to work together towards a common goal (Søresen \& Hasle, 2009), especially under high levels of perceived uncertainty. The way in which leaders deal with challenging events (e.g. layoffs or downsizing), may directly influence the level of trust that employees have in their leaders (Tourish, Paulsen, Hobman, \& Bordia, 2004).

\section{Precariousness and job insecurity}

Instability and flexibility of the modern labour market have led to increased feelings of uncertainty, insecurity, and precariousness in the work environment (Urbini, Lo Presti,
Chirumbolo, \& Callea, 2020). The concept of precarity has its origin in French sociology and economics. Precarity initially referred to a social condition linked to poverty and only later referred to a different form of employment than the familiar permanent employment relationship (Barbier, 2002). The concept of precarity emerged from the early 2000s onwards and is characterised by increasingly insecure employment and generalised uncertainty and insecurity (Lazar \& Sanchez, 2019). The consequences of precarious work and related job insecurity were exacerbated by the global economic crisis of 2008. The precariousness in the work environment has increased as countries attempted to respond to weakening financial situations and the increasingly fragile economy (Kalleberg, 2018).

Job insecurity refers to the unintended concern employees have concerning the future continuity of their jobs (Vander Elst, De Witte, \& De Cuyper, 2014). The decision to measure precariousness because of job insecurity was informed by the statement of Fullerton, McCollum, Dixon and Anderson (2020) that job insecurity is a crucial element of precarious work and precariousness. Change and optimisation in the workplace is synonymous with uncertainty about the future content of an employee's job (qualitative job insecurity) as well as the risk of job loss (quantitative job insecurity) (Urbini et al., 2020). Greenhalgh and Rosenblatt (2010) maintained that perceived job insecurity can have a destructive impact on employees and organisations. Additionally, job insecurity is linked to reduced levels of job satisfaction, organisational commitment, job performance, poor employee well-being (Lee, Huang, \& Ashford, 2018), and decreased optimism about the future $(\mathrm{Li}, \mathrm{Li}, \mathrm{Fay}, \&$ Frese, 2019).

\section{Association of authentic leadership with trust in the leader and the potential impact of precariousness (job insecurity)}

Brower, Lester, Korsgaard and Dineen (2009) pointed out that trust is a crucial element in the supervisor-follower relationship. When authentic leaders exhibit behaviour in accordance with their personal values, they are able to build credibility, respect and trust with their team members through the encouragement of different perspectives and building synergetic relationships with them (Avolio et al., 2004). Kernis (2003) posited that the authentic leader's relational authenticity involves striving for achieving openness and truthfulness in their relationship with their followers and colleagues, which may result in elevated levels of trust. Several studies found that AL significantly impacts trust in leaders (Levesque-Côté, Fernet, Austin, \& Morin, 2018; Maximo et al., 2019).

Clapp-Smith et al. (2009) maintained that trust can be described as the vulnerability of one person to another person's actions while being convinced that the actions of the other person will be carried out with good intentions. The willing exchange of actions between individuals also forms part of a trusting relationship. When the trusting 
employee believes that exploitation is unlikely, there will be a willingness to risk vulnerability, and a display of trusting behaviour (Eggers, 2011). Agote et al. (2016) stated that TL will influence followers' attitudes and behaviour. Trust in the leader was positively related to job performance, positive attitudes towards jobs and organisations and organisational citizenship behaviour (Colquitt, Scott, \& LePine, 2007). In contrast, employees who do not trust their leader are less likely to do more than what is expected of them or remain in the relationship because of the lack of a sense of obligation and low positive expectations (Brower et al., 2009). Additionally, because of the behaviour of untrustworthy leaders, the performance of employees may be compromised as a result of their concern of being treated unfairly (Mayer \& Gavin, 2005).

As a result of the dynamic business environment in which employees are functioning presently, they frequently experience job insecurity since they feel that the future of their employment might be at risk (Richter \& Näswall, 2019). Job insecurity has consequently become a familiar stressor in working life (Lee et al., 2018). Jiang and Lavaysse (2018) maintained that living in constant uncertainty and fear that their working life may be subjected to substantial changes at any time may adversely affect employees as well as organisations. Prior job insecurity-related research suggests that feeling uncertain about the future of one's employment can be associated with several short (Cheng \& Chan, 2008) and long-term negative consequences (De Witte et al., 2016). According to Arnold and Staffelbach (2012), trust in the organisation has been shown to negatively relate to job insecurity and perceived uncertainty during organisational restructuring and optimisation. Moreover, Huie, Cassaberry and Rivera (2020) argued that job insecurity may result in the loss of trust, jealousy and destructive competitiveness in a work context. This can potentially be viewed as the deterioration of the employee's relationship with the employer and may result in reduced job satisfaction and employee wellbeing (Richter \& Näswall, 2019). Mistrust forms the base of unsuccessful business relationships as it directly influences knowledge sharing that harms job performance and economic progress (Huie et al., 2020). Additionally, the future retention of employees with low levels of trust is likely to be negatively affected (Hopkins \& Weathington, 2006).

Bases on the above, the research questions of this study were formulated as follows:

- What are the effects of perceived AL on TL?

- To what extent does precariousness in the form of job insecurity correlates with AL and TL?

\section{Research design Research approach}

The researchers utilised a quantitative approach, together with a cross-sectional survey design during this study.

\section{Research participants}

The study population comprised of employees from three managerial levels consisting of senior, middle, and junior managers working at the different plant sites of a South African manufacturing organisation. The questionnaires were distributed to 570 employees, and 314 completed questionnaires were received back, representing a response rate of $55 \%$. Data collection was conducted via stratified random sampling.

Table 1 depicts the participants' characteristics: $41.7 \%$ of the respondents indicated that they were in the 51-60 age bracket, $22.2 \%$ were employed at manager level, $30.5 \%$ of the participants had $31-40$ years of service, $87.5 \%$ had up to 20 years of experience in their current position. More than half of the participants stated that they are employed at Vanderbijlpark works in Gauteng (51.9\%), and $17.8 \%$ at the Newcastle production facility in KwaZulu-Natal.

\section{Measuring instruments}

After having filled in the biographical questionnaire, participants were requested to complete instruments for measuring AL, precarity, and TL. The Authentic Leadership Inventory (ALI) (Neider \& Schriesheim, 2011) was used to measure the followers' perceptions of their direct leader's AL characteristics. The ALI consists of four dimensions (selfawareness, internal moral perspective, balanced processing, and relational transparency), measured by means of 14 items. Example items include: 'My leader asks for ideas that challenge his or her core beliefs' and 'My leader objectively analyses relevant data before making a decision'. A five-point Likert-type scale ranging from 1 (strongly disagree) to 5 (strongly agree) was applied to score the items. Cronbach's

\begin{tabular}{|c|c|c|c|}
\hline Item & Category & Frequency & $\%$ \\
\hline \multirow[t]{5}{*}{ Age group } & $20-30$ years & 7 & 2.2 \\
\hline & $31-40$ years & 39 & 12.4 \\
\hline & $41-50$ years & 126 & 40.1 \\
\hline & $51-60$ years & 131 & 41.7 \\
\hline & $\geq 61$ years & 11 & 3.5 \\
\hline \multirow[t]{3}{*}{ Job category } & Senior manager & 41 & 13.0 \\
\hline & Manager & 70 & 22.2 \\
\hline & Junior Manager & 203 & 64.7 \\
\hline \multirow[t]{5}{*}{ Experience } & $0-10$ years of service & 39 & 12.4 \\
\hline & $11-20$ years of service & 60 & 19.1 \\
\hline & $21-30$ years of service & 105 & 33.4 \\
\hline & $31-40$ years of service & 96 & 30.5 \\
\hline & $41-45$ years of service & 14 & 4.5 \\
\hline \multirow[t]{5}{*}{ Years in current position } & $0-10$ years & 199 & 63.3 \\
\hline & $11-20$ years & 76 & 24.2 \\
\hline & $21-30$ years & 27 & 8.6 \\
\hline & $31-40$ years & 10 & 3.1 \\
\hline & $41-45$ years & 2 & 0.6 \\
\hline \multirow[t]{4}{*}{ Operating area } & Vanderbijlpark works & 163 & 51.9 \\
\hline & Newcastle works & 56 & 17.8 \\
\hline & Gauteng operations & 26 & 8.3 \\
\hline & Corporate services & 69 & 22.0 \\
\hline
\end{tabular}




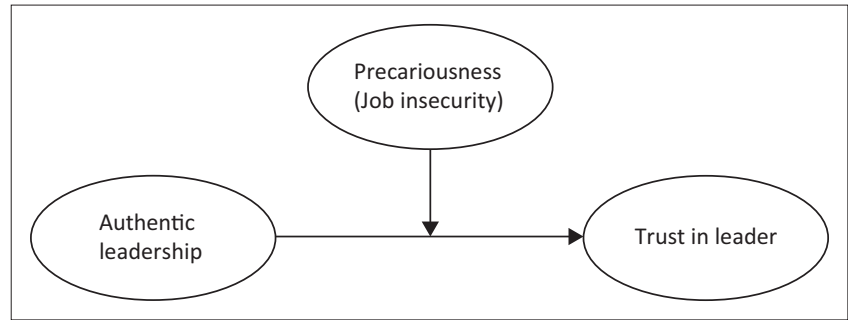

FIGURE 1: The research model.

alpha coefficients between 0.74 and 0.90 are acceptable (Men \& Stacks, 2014). The reliability of ALI was also tested in South Africa ( $\alpha=0.93$; Stander, De Beer, \& Stander, 2015).

One scale of the Workplace Trust Survey (WTS) (Ferres \& Travaglione, 2003), consisting of 9 items, measured TL. Mentioned items were scored by applying a seven-point Likert-type scale ranging from 1 (strongly disagree) to 7 (strongly agree). Examples of the items include: 'I feel that my supervisor listens to what I have to say' and 'I believe that my supervisor follows through words with action' (Ferres \& Travaglione, 2003). Previous studies in both a South African and Australian context have reported Cronbach alpha reliability coefficients of between 0.90 and 0.97 (Ferres \& Travaglione, 2003).

Job insecurity was measured by applying the Job Insecurity Scale (JIS) - a scale consisting of four items initially developed by De Witte (2000). This scale is a global job insecurity measure, and it includes items that refer to the threat or possibility of losing a job, as well the anxiety associated with job loss. Examples of the items include: 'I feel insecure about the future of my job', and 'I think I might lose my job in the near future'. Respondents were requested to rate these items on a five-point Likert type scale, ranging from 1 (strongly disagree) to 5 (strongly agree). The Cronbach alpha reliability coefficient was recorded as 0.77 (Vander Elst et al., 2014).

\section{Research procedure and ethical considerations}

The Chief Executive Officer granted permission for the study to be performed at the participating manufacturing company. A higher education institution gave scientific and ethical clearance for this study. Before participating in the study, participants completed a consent form. An information brochure describing the purpose of the research and ethical considerations accompanied the questionnaire.

\section{Ethical considerations}

Ethical approval was granted by the Economic and Management Sciences Research Ethics Committee (EMS-REC) at North-West University, reference number: NWU- 00609-20-A4.

\section{Statistical analysis}

Mplus 8.4 was utilised to analyse the data related to this study (Muthén \& Muthén, 1998-2019). Confirmatory factor analyses (CFA) were performed to determine the validity of the instrument and identify the best-fitting measurement model. Structural equation modelling (SEM) was applied to assess how the data fitted various structural models and to test the research model. The items of all questionnaires were dealt with as continuous. The mean-adjusted Maximum Likelihood (MLM) estimator, which is robust to the nonnormality of data (Wang \& Wang, 2020), was used because of all values being recorded.

The best-fit model was identified using the Chi-square values, which were calculated to evaluate absolute fit. The incremental fit was determined by applying the Comparative Fit Index (CFI) and the Tucker-Lewis Index (TLI). Wang and Wang (2020) deemed 0.90 an appropriate cut-off value for these two fit indices. The Root Mean Square Error of Approximation (RMSEA) and Standardised Root Mean Square Residual (SRMR) were also evaluated. The RMSEA values less than 0.08 represent an acceptable fit (Kline, 2016). Values lower than 0.05 are accepted as an indication of a good fit between the data and the model for the SRMR indicator (Wang \& Wang, 2020). The SRMR values closer to 0.08 indicate an acceptable fit between the model and the data (Wang \& Wang, 2020). The comparative fit indices, Akaike information criterion (AIC) and the Bayes information criterion (BIC) were used to compare the different measurement and structural models. Kline (2016) mentioned that the model with the lowest value is preferred. Composite reliability coefficients with a minimum value of 0.70 were employed to determine measuring instrument reliability (Wang \& Wang, 2020). The internal consistency of constructs was established by utilising composite reliability (Raykov, 2009). A simple moderator analysis was performed during this study by using PROCESS (Hayes, 2018).

\section{Results \\ Testing the measurement model}

To evaluate the possible relationships between the latent variables, a three-factor measurement model (Model 1) was specified and tested for fit to the observed data. Additionally, one competing model was identified and tested to confirm the fit of the preferred model.

Model 1 was constructed in line with what theory proposes: AL (measured as second-order construct), TL (measured by nine directly observed variables) and job insecurity (measured utilising four directly observed variables).

Model 2 was specified similar to Model 1 with the exception that AL was specified as a first-order latent variable measured employing only 14 directly observed variables.

The results for model 1 reflected that the Chi-square test was significant $(p<0.001)$, with a Chi-square $\left(\chi^{2}\right)$ value of 506.189 and a degrees of freedom ( $d f$ ) value of 317, suggesting that a perfect fit to the data was not achievable. As a result of the oversensitivity of the measure of fit, Hancock and Mueller (2010) recommended that researchers 
TABLE 2: Competing measurement model fit statistics.

\begin{tabular}{|c|c|c|c|c|c|c|c|c|c|}
\hline Model & $\chi^{2}$ & $d f$ & CFI & TLI & RMSEA & $90 \% \mathrm{Cl}$ & SRMR & AIC & BIC \\
\hline Model 1 & $506.189 *$ & 317 & 0.959 & 0.954 & 0.044 & $0.036-0.051$ & 0.035 & 19783.448 & 20113.394 \\
\hline Model 2 & $518.642 *$ & 321 & 0.957 & 0.953 & 0.044 & $0.037-0.051$ & 0.035 & 19790.696 & 20105.646 \\
\hline
\end{tabular}

$\chi^{2}$, chi-square statistic; $d f$, degree of freedom; CFI, Comparative fit Index; TLI, Tucker-Lewis Index; RMSEA, Root Mean Square Error of Approximation; SRMR, Standardised Root Mean-square Residual; AIC, Akaike Information Criterion; BIC, Bayes Information Criterion; $\mathrm{Cl}$, Confidence Interval.

$*, p=0.000$.

TABLE 3: Correlation matrix containing means, standard deviations and reliabilities.

\begin{tabular}{lccccc}
\hline Variable & $\boldsymbol{M}$ & s.d. & $\boldsymbol{\rho}$ & $\mathbf{1}$ & $\mathbf{2}$ \\
\hline 1. Authentic leadership & 3.607 & 0.646 & 0.985 & - & - \\
2. Trust in leader & 5.249 & 1.208 & 0.960 & $0.820 * *$ & - \\
3. Job insecurity & 3.209 & 0.642 & 0.709 & -0.137 & -0.158 \\
\hline
\end{tabular}

$M$, mean; s.d., standard deviation; $\rho$, composite reliability coefficient.

$\dagger, r>0.30 ;, r>0.50$.

$*, p<0.05$.

TABLE 4: Standardised regression coefficients of authentic leadership and job insecurity in predicting trust in the leader.

\begin{tabular}{lcccc}
\hline Variable & E & s.e. & E/s.e. & $p$ \\
\hline Trust in leader on & & & & \\
Authentic leadership & 0.814 & 0.027 & 30148 & $0.000^{*}$ \\
Job insecurity & -0.046 & 0.043 & -1070 & 0.284 \\
\hline
\end{tabular}

$\mathrm{E}$, estimate; s.e., standard error; $p$, probability.

$*, p<0.01$.

consider reporting multiple fit indices. The alternative fit indices indicated that an approximate fit to the data was attainable: Both CFI and TLI were above the cut-off value of 0.90, RMSEA indicated a good fit $(<0.05, p>0.05)$. The SRMR value of less than 0.08 also indicated a good fit (Wang \& Wang, 2020).

Table 2 presents the goodness-of-fit statistics for the competing measurement models described above. Table 2 indicates that Model 1 has the best statistical fit of the two models under review. The initial measurement model obtained an $\chi^{2}$ value of 506.189 and a $d f$ value of 317 . The fit indices for CFI and TLI were also acceptable $(>0.90)$, as was the model fit for the RMSEA $(<0.05)$. The SRMR value for Model 1 was acceptable $(<0.08)$ and was equal to the value of the alternative model. Lastly, the AIC and BIC fit indices were used to compare models to identify the best fit (lowest value). Model 1 had the lowest AIC value, and Model 2 had the lowest BIC value.

As part of the Model 2 results, the chi-square results were once again significant $\left(\chi^{2}=518.642, d f=321, p<0.0001\right)$. The alternative fit indices represented by the TLI and CFI values being higher than 0.90 were acceptable. Lastly, both the RMSEA $(p>0.05)$ and SRMR $(<0.05)$ values were also acceptable.

Although acceptable comparative fit indices were indicated for both competing models, the CFI (0.959) and TLI (0.954) values and the RMSEA confidence intervals of Model 1 pointed to this model being the best fit to the data. Additionally, with the lowest AIC value of 19783.448 , it is suggested that Model 1 had the best data fit. However, the BIC value pointed to Model 2 as being the best-fitting model. When evaluating all the fit indices in conjunction, Model 1, which was also the model that most closely represented theory, was chosen as the preferred model.

\section{Testing structural models}

The structural model was tested based on the chosen measurement model and resulted in similar fit statistics as was obtained from the measurement model. The results in Table 3 indicate that the Raykov's rho coefficients were well above the minimum threshold with values above 0.9 and are thus considered highly reliable. The Raykov's rho coefficients of all the measuring instruments ranged from 0.709 to 0.985 and were deemed acceptable. Furthermore, Table 3 provides the correlation coefficients of the study variables. The AL was found to be significantly related to TL $(r=0.820)$, and $\mathrm{AL}$ and job insecurity are inversely related $(r=-0.137$; $p<0.05)$.

Table 4 depicts the path coefficients of the structural model (Model 3) as estimated by Mplus 8.4 (Muthén \& Muthén, 1998-2019). Table 4 also portrays the standard path coefficients for AL and job insecurity as independent variables and trust as a dependent variable.

As can be deducted from Table $4, \mathrm{AL}$ is a significant predictor of TL $(\beta=0.814 ; p<0.01)$. However, job insecurity was not significantly associated with TL $(\beta=-0.046 ; p>$ 0.05). Authentic leadership explains $45.43 \%$ of the variance in TL.

\section{Moderating effect}

To test whether the relationship between AL (independent variable) and TL (dependent variable) depends on the extent to which employees experience job insecurity (moderator), a simple moderator analysis was performed using PROCESS (Hayes, 2018). The interaction between AL and job insecurity was not statistically significant $(\beta=-0.036,95 \% \mathrm{CI}, \mathrm{LCI}=-0.242$, $\mathrm{UCI}=0.170$ ). Therefore job insecurity cannot be considered a moderator of the relationship between AL and TL.

\section{Discussion \\ Outline of the results}

The objectives of this study were to determine whether the AL style can predict TL among the selected sample of employees from various functions in a manufacturing organisation in South Africa. More specifically, the study was conducted to gain knowledge and understanding of how AL can potentially enhance TL despite the turbulent economic and business conditions experienced in the target 
organisation. The potential moderating effect of job insecurity on the relationship between AL and TL was also tested:

\section{- What are the effects of perceived AL on TL?}

The results of this study confirmed the first part of our research question by indicating that AL directly and positively influences TL - higher AL lead to increased TL. This result also confirms the outcome of previous studies on $\mathrm{AL}$ that found that $\mathrm{AL}$ is a positive predictor of TL (Maximo et al., 2019; Qiu, Alizadeh, Dooley, \& Zhang, 2019).

Authentic leaders are able to establish engaging and constructive organisational conditions because of them being profoundly aware of their values and beliefs, and being genuine, dependable and trustworthy (Avolio and Gardner 2005). Gardner et al. (2005) put forth that authentic leaders can develop trust in team members through their ability to be conscious of their capabilities and shortcomings and disclosing their real self to others while being sensitive to the impact their actions may have on others. Additionally, high self-awareness levels have been associated with positive follower attitude, behaviour, and performance (Avolio \& Gardner, 2005) and, in this study, trust. One of the prerequisites of trust is to possess knowledge of and insight into the other person. The leader who is willing to allow his employees to get to know them has a better chance to instil trust in their leadership. Relational transparency is a component of $\mathrm{AL}$ that relates to the open sharing of information and exhibiting true emotions to others, resulting in elevated trust between leaders and employees (Iqbal et al., 2020). The sharing of information and emotions will create a psychologically safe environment where the employee will become more open about their feelings and needs. By feeling comfortable, employees will easily share positive experiences and concerns, leading to healthy trustful relationships. When employees experience that there are no hidden agendas, their TL will increase. Trust is likely to influence individual cooperation levels within a relationship (Norman, Avolio, \& Luthens, 2010). Such behaviour can result in developing positive follower qualities such as optimism and confidence in the work situation. Authentic leaders may also instil enhanced admiration in their followers by demonstrating their internalised moral perspective through applying high moral standards and ethical behaviours (Ilies et al., 2005) rather than being influenced by external pressures and opinions. These leaders behave transparently towards their followers and lead by example while guided by characteristics such as honesty, fairness, and accountability. When employees perceive that they are being treated fairly and morally by their supervisor, they might trust their leader while being more engaged at work (Cropanzano \& Mitchell, 2005; Norman, 2006). If followers perceive that they are being treated unfairly, they will trust that leader less.

Awareness of the leader's values, and even more critical, alignment between the leader and employee's values, creates a climate in which there are fewer reasons not to mistrust the leader. Lastly, an authentic leader's ability to consider all available information in an unbiased and balanced manner before reaching a final decision (Penger \& Černe, 2014) can reinforce the sense of confidence employees have in their leader's decisions. This approach may result in actions that are well-planned and thought through. Although the decision-making processes that authentic leaders follow might be a bit more time-consuming, the methodology they follow might be beneficial in new and uncertain situations. A balanced approach will reinforce the employees' perceptions that the leader acts in the organisation's best interest and its employees, without bias towards specific individuals.

Flavian, Guinaliu and Jordan (2019) mentioned that when employees trust their leader, they are likely to have positive expectations about their intentions and behaviours since they have confidence that their leader will have their best interest at heart. When high levels of TL exist, followers are more likely to exhibit a readiness to face vulnerability during times of uncertainty as a result of their positive perception of the supervisor's intentions and behaviour (Zhang \& Zhou, 2014). The findings of a study conducted by Bligh (2017) underlines the importance of this result as it emphasises the vital role TL can play in improving organisational performance. The trust between leaders, and team members notably influenced employee-related outcomes such as turnover intentions and engagement through the reduction of workplace uncertainty and strengthening the social exchange relationship (Skiba \& Wildman, 2019):

- To what extent does precariousness in the form of job insecurity moderate the association between AL and TL?

In contrast to expectations, no evidence could be found that job insecurity will moderate the direct and indirect associations between AL and TL. This implies that a variation in job insecurity levels will have no influence on the magnitude or direction of the relation linking AL and TL.

When employees regard their leader as trustworthy, it is plausible that they will feel safer and more optimistic about the leader making crucial decisions (Jiang \& Probst, 2019) despite the lack of guarantees. One can assume that authentic leaders are able to demonstrate their concern for employee wellbeing through their lack of bias while considering all available and relevant information before reaching a final decision (Leroy et al., 2012), even during restructuring and workforce reduction initiatives.

Drawing from the Social Exchange Theory (Blau, 1964), it might be said that when employees trust their leader, these employees may deem it a relationship of social exchange while being convinced that the leader will reciprocate the trusting behaviour. The inherent principle of reciprocity suggests that an individual's behaviour depends on the give and take relationship between one person (leader) and another (follower). It might thus be possible that because employees trust their leader and are dedicated to their work, they expect that the supervisor will 'return the favour' by considering their wellbeing when making decisions during 
an organisational optimisation and workforce reduction process. Moreover, because team members have trust in their leaders and their decision-making ability, they might have faith that the leader will make a decision that will have their best interest at heart. The unfortunate reality that the manufacturing organisation where the study was conducted had to undergo numerous restructuring and down-sizing initiatives over the past number of years might also have resulted in employees exhibiting a certain level of reduced fear for the unknown and willingness to face the risks of the potential loss or change in the content of their jobs.

This study addressed the identified research gap by firstly confirming the relationship between a positive leadership style, such as AL and TL. Secondly, the study added theoretical value by suggesting that job insecurity as a form of business-related precariousness does not have a moderating effect on the relationship between AL and TL.

\section{Practical implications}

Leaders can be successfully developed provided the leadership development intervention used has been proven effective and that both the leader and the organisation are developmentally ready to embrace leadership development (Avolio \& Hannah, 2020). Organisations should thus consider including $\mathrm{AL}$ elements in their selection, training, and rating activities to benefit from AL. As part of their succession planning and leadership development processes, organisations might want to consider the inclusion of $\mathrm{AL}$ training in order to prepare future leaders. Organisations should afford leaders on all levels the opportunity to develop their AL capabilities. Aside from earning the trust of their followers, leaders must also be educated to increase perceptions of their authenticity by behaving in line with their beliefs or by 'practising what they preach' and being open and honest towards their team members as well as themselves.

\section{Limitations and recommendations}

Various study limitations should be noted when interpreting the study results. Firstly, using a cross-sectional design limited the ability to make causal inferences between research variables. Employing self-report questionnaires as the only source of information for the study may result in common method variance. On account of the research being conducted at only one manufacturing organisation in the steel manufacturing industry in South Africa, the extrapolation of results to different environments should be made with caution.

Regardless of the mentioned research limitations, the following proposals could be considered in future studies. The fact that the study was conducted by only involving managers leaves the question as to whether involving employees on lower levels (e.g. less educated, blue-collar) would have resulted in the same outcome. New insights into the potential influence of a precarious work environment could also be gained by conducting a longitudinal or mixed- methods study. Future studies might want to include trust in the organisation, since the possibility exists that job insecurity might have a closer relation to trust in the organisation than to AL.

The results of this study underscore that promoting AL is a promising pathway for improved follower trust levels in their leader, which may ultimately benefit individual and organisational performance. The benefit of promoting trust within an organisation is highlighted in a study by Koohang, Paliszkiewicz and Goluchowski (2017), who found that trust is a critical factor in social and economic relationships as well as a significant contributing factor to organisational performance. The non-moderating effect of job insecurity may imply that even employees with high job insecurity will have trust in their leader. The researchers are of the opinion that organisations will benefit from developing authentic leaders.

\section{Conclusion}

Despite the mentioned limitations, the present study demonstrates the potential positive impact of $\mathrm{AL}$, as perceived by team members, on the level of trust they have in their leader. Authentic leadership entrenchment might thus lead to increased employee trust in their supervisor in manufacturing organisations even if the organisation is functioning in a volatile and uncertain business context. When employees trust their leaders, it may strengthen their intention to stay with the organisation and contribute to its successful functioning. Those as mentioned above could be ascribed to the harmonious environment that trusted leaders can create and the influence it may have on the attitudes and behaviours of followers (Yurtkoru et al., 2018).

\section{Acknowledgements}

The authors would like to acknowledge the manufacturing company and its employees who participated in the study.

\section{Competing interests}

The authors declare that they have no financial or personal relationships that may have inappropriately influenced them in writing this article.

\section{Author's contributions}

D.J.K. acted as first author (as the article is partially based on his thesis with M.M.H. as promotor and M.W.S. as copromotor). M.H. acted as statistical specialist. M.M.H. and M.W.S. contributed towards the conceptualisation, review, and editing of the article.

\section{Funding information}

This research received no specific grant from any funding agency in the public, commercial or not-for-profit sectors. 


\section{Data availability}

The authors confirm that the data supporting the findings of this study are available within the article and the raw data that support the findings are available from the corresponding author, M.M.H., upon reasonable request. The main consideration for this was based on the ethical clearance conditions stipulated for this study in order to protect the organisation of interest.

\section{Disclaimer}

The views and opinions expressed in this article are those of the authors and do not necessarily reflect the official policy or position of any affiliated agency of the author.

\section{References}

Agote, L., Aramburu, N., \& Lines, R. (2016). Authentic leadership perception, trust in the leader, and followers' emotions in organizational change processes. Journal of Applied Behavioural Science, 52(1), 35-63. https://doi.org/10.1177/002188 Applied Behavi
6315617531

Arnold, A., \& Staffelbach, B. (2012). Perceived post-restructuring job insecurity: The impact of employees' trust in one's employer and perceived employability. German Journal of Human Resource Management: Zeitschrift für Personalforschung, 26(4), Journal of Human Resource Management: Zeitschrift für
307-330. https://doi.org/10.1177/239700221202600405

Avolio, B.J., \& Gardner W.L. (2005). Authentic leadership development: Getting to the root of positive forms of leadership. The Leadership Quarterly, 16(3), 315-338. https://doi.org/10.1016/j.leaqua.2005.03.001

Avolio, B.J., \& Hannah, S.T. (2020). An enduring leadership myth: Born a leader or made a leader? Organizational Dynamics, 49(4), 1-8. https://doi.org/10.1016/j. orgdyn.2019.08.002

Avolio, B.J., Luthans, F., \& Walumbwa, F.O. (2004). Authentic leadership: Theory building for veritable sustained performance. Working paper. Lincoln: Gallup Leadership Institute, University of Nebraska.

Avolio, B.J., Walumbwa, F.O., \& Weber, T.J. (2009). Leadership: Current theories, research, and future directions. Annual Review of Psychology, 60, 421-449. https://doi.org/10.1146/annurev.psych.60.110707.163621

Baker, N. (2020). Authentic leadership, leader anger and follower job outcomes: A comparison of angry vs. non-angry leaders. Beykoz Akademi Dergisi, 8(2), 106126. https://doi.org/10.14514/BYK.m.26515393.2020.8/2.106-126

Bamford, M., Wong, C.A., \& Laschinger, H. (2013). The influence of authentic leadership and areas of worklife on work engagement of registered nurses. leadership and areas of worklife on work engagement of registered nurses.
Journal of Nursing Management, 21(3), 529-540. https://doi.org/10.1111/ Journal of Nursing Manage
j.1365-2834.2012.01399.x

Barbier, J.-C. (2002). A survey of the use of the term précarite in French economics and sociology. Working paper no. 19. CNRS/Centre d'Etudes de l'Emploi. Retrieved from https://www.researchgate.net/publication/237692330_A_survey_of_the use_of_the_term_precarite_in_French_economics_and_sociology

Barrech, A., Baumert, J., Gündel, H., \& Ladwig, K. (2018). The impact of job insecurity on long-term self-rated health - Results from the prospective population-based MONICA/KORA study. BMC Public Health, 18(754), 1-10. https://doi.org/10.1186/ s12889-018-5621-4

Blau, P.M. (1964). Exchange and power in social life. New York, NY: Wiley.

Bligh, M.C. (2017). Leadership and trust. In J. Marques \& S. Dhiman (Eds.), Leadership today: Practices for personal and professional performance (pp. 21-42). Springer, Cham.

Breakwell, G.M. (2020). Mistrust, uncertainty and health risks. Contemporary Social Science, 15(5), 504-516. https://doi.org/10.1080/21582041.2020.1804070

Brower, H.H., Lester, S.W., Korsgaard, M.A., \& Dineen, B.R. (2009). A closer look at trust between managers and subordinates: Understanding the effects of both trusting and being trusted on subordinate outcomes. Journal
35(2), 327-347. https://doi.org/10.1177/0149206307312511

Burke, C.S., Sims, D.E., Lazzara, E.H., \& Salas, E. (2007). Trust in leadership: A multilevel review and integration. The Leadership Quarterly, 18(6), 606-632. https:// doi.org/10.1016/j.leaqua.2007.09.006

Cheng, G.H.L., \& Chan, D.K.S. (2008). Who suffers more from job insecurity? A metaanalytic review. Applied Psychology, 57(2), 272-303. https://doi.org/10.1111/ j.1464-0597.2007.00312.x

Ciftci, E.G. (2020). Authentic leadership. In O. Demirtas \& M. Karaca (Eds.), A handbook of leadership styles (pp. 211-230). Cambridge Scholars, Newcastle upon Tyne.

Clapp-Smith, R., Vogelgesang, G.R., \& Avey, J.B. (2009). Authentic leadership and positive psychological capital: The mediating role of trust at the group level of analysis. Journal of Leadership \& Organizational Studies, 15(3), 227-240. https:// doi.org/10.1177/1548051808326596

Colquitt, J.A., Scott, B.A., \& LePine, J.A. (2007). Trust, trustworthiness, and trust propensity: A meta-analytic test of their unique relationships with risk taking and job performance. Journal of Applied Psychology, 92(4), 909-927. https://doi. org/10.1037/0021-9010.92.4.909
Copeland, M.K. (2016). The impact of authentic, ethical, transformational leadership on leader effectiveness. Journal of Leadership, Accountability and Ethics, 13(3), 79-97.

Cropanzano, R., \& Mitchell, M.S. (2005). Social exchange theory: An interdisciplinary review. Journal of Management, 31(6), 874-900. https://doi.org/10.1177/ 0149206305279602

De Witte, H. (2000). Arbeidsethos en jobonzekerheid: Meting en gevolgen voor welzijn, tevredenheid en inzet op het werk. In R. Bouwen, K. De Witte, H. De Witte, \& T. Taillieu (Eds.), Van groep tot gemeenschap (pp. 325-350). Leuven: Garant.

De Witte, H., Pienaar, J., \& De Cuyper, N. (2016). Review of 30 years of longitudinal studies on the association between job insecurity and health and well-being: Is there causal evidence? Australian Psychologist, 51(1), 18-31. https://doi. org/10.1111/ap.12176

Eggers, J.T. (2011). Psychological safety influences relationship behavior. Corrections Today, 73(1), 60-61.

Ferres, N., \& Travaglione, T. (2003, December). The development and validation of the workplace trust survey (WTS): Combining qualitative and quantitative methodologies. Paper presented at APROS, December 2003. Mexico.

Flavian, C., Guinaliu, M., \& Jordan, P. (2019). Antecedents and consequences of trust on a virtual team leader. European Journal of Management and Business Economics, 28(1), 2-24. https://doi.org/10.1108/EJMBE-11-2017-0043

Fullerton, A.S., McCollum, D.B., Dixon, J.C., \& Anderson, K.F. (2020). The insecurity gradient in health: How inequality in the distribution of job insecurity matters for the relationship between job insecurity and self-rated health in Europe. The Sociological Quarterly, 61(1), 107-127. https://doi.org/10.1080/00380253.2019. 1581038

Gardner, W.L., Avolio, B.J., Luthans, F., May, D.R., \& Walumbwa, F. (2005). 'Can you see the real me?'. A self-based model of authentic leader and follower development. The Leadership Quarterly, 16(3), 343-372. https://doi.org/10.1016/j.leaqua. 2005.03.003

Greenhalgh, L., \& Rosenblatt, Z. (2010). Evolution of research on job insecurity International Studies of Management \& Organization, 40(1), 6-19. https://doi. org/10.2753/IMO0020-8825400101

Hancock, G.R., \& Mueller, R.O. (Eds.). (2010). The reviewer's guide to quantitative methods in the social sciences (1st ed.). New York, NY: Routledge.

Hayes, A.F. (2018). Partial, conditional, and moderated moderated mediation: Quantification, inference, and interpretation. Communication Monographs, 85(1), 4-40. https://doi.org/10.1080/03637751.2017.1352100

Heyns, M., \& Rothmann, S. (2015). Dimensionality of trust: An analysis of the relations between propensity, trustworthiness and trust. SA Journal of Industrial Psychology, 41(1), 1-12. https://doi.org/10.4102/sajip.v41i1.1263

Hopkins, S.M., \& Weathington, B.L. (2006). The relationships between justice perceptions, trust, and employee attitudes in a downsized organization. The Journa of Psychology, 140(5), 477-498. https://doi.org/10.3200/JRLP.140.5.477-498

Huie, C.P., Cassaberry, T., \& Rivera, A.K. (2020). The impact of tacit knowledge sharing on job performance. The International Journal on Social and Education Sciences, 2(1), 34-40.

Ilies, R., Morgeson, F.P., \& Nahrgang, J.D. (2005). Authentic leadership and eudaemonic well-being: Understanding leader-follower outcomes. The Leadership Quarterly, 16(3), 373-394. https://doi.org/10.1016/j.leaqua.2005.03.002

Iqbal, S., Farid, T., Khan, M.K., Zhang, Q., Khattak, A., \& Ma, J. (2020). Bridging the gap between authentic leadership and employees' communal relationships through trust. International Journal of Environmental Research and Public Health, 17(1) 250. https://doi.org/10.3390/ijerph17010250

Iverson, R.D., \& Zatzick, C.D. (2011). The effects of downsizing on labor productivity: The value of showing consideration for employees' morale and welfare in highperformance work systems. Human Resource Management, 50(1), 29-44. https:// doi.org/10.1002/hrm.20407

James, L.J. (2011). The relationship between perceived organisational support and workplace trust: An exploratory study. Master's dissertation. Retrieved from https://etd.uwc.ac.za/xmlui/bitstream/handle/11394/3188/James MCOM_2011.pdf?seqence=1

Jiang, L., \& Lavaysse, L.M. (2018). Cognitive and affective job insecurity: A metaanalysis and a primary study. Journal of Management, 44(6), 2307-2342. https:// doi.org/10.1177/0149206318773853

Jiang, L., \& Probst, T.M. (2019). The moderating effect of trust in management on consequences of job insecurity. Economic and Industrial Democracy, 40(2), 409-433. https://doi.org/10.1177/0143831X16652945

Kalleberg, A.L. (2018). Precarious lives: Job insecurity and well-being in rich democracies (1st ed.). Polity Press, Cambridge.

Karamat, A.U. (2013). Impact of leadership on organizational performance. Unpublished doctoral thesis. University of Applied Sciences.

Keim, A.C., Landis, R.S., Pierce, C.A., \& Earnest, D.R. (2014). Why do employees worry about their jobs? A meta-analytic review of predictors of job insecurity. Journal of Occupational Health Psychology, 19(3), 269-290. https://doi.org/10.1037/a0036743

Kernis, M.H. (2003). Toward a conceptualisation of optimal self-esteem. Psychological Inquiry, 14(1), 1-26. https://doi.org/10.1207/S15327965PLI1401_01

Kline, R.B. (2016). Principles and practice of structural equation modeling (4th ed.). New York, NY: Guilford Press.

Koohang, A., Paliszkiewicz, J., \& Goluchowski, J. (2017). The impact of leadership on trust, knowledge management, and organizational performance: A research
model. Industrial Management \& Data Systems, 117(3), 521-537. https://doi. model. Industrial Management \&
org/10.1108/IMDS-02-2016-0072 
Kouzes, J.M., \& Posner, B.Z. (2007). The leadership challenge (4th ed.). San Francisco, CA: Jossey-Bass. Lazar, S., \& Sanchez, A. (2019). Understanding labour politics in an age of precarity
Dialectical Anthropology, 43(1), 3-14. https://doi.org/10.1007/s10624-019-09544-7

Lee, C., Huang, G.-H., \& Ashford, S.J. (2018). Job insecurity and the changing workplace: Recent developments and the future trends in job insecurity research Annual Review of Organizational Psychology and Organizational Behavior, 5(1) 335-359. https://doi.org/10.1146/annurev-orgpsych-032117-104651

Leroy, H., Palanski, M.E., \& Simons, T. (2012). Authentic leadership and behavioral integrity as drivers of follower commitment and performance. Journal of Business Ethics, 107(3), 255-264. https://doi.org/10.1007/s10551-011-1036-1

Levesque-Côté, J., Fernet, C., Austin, S., \& Morin, A.J.S. (2018). New wine in a new bottle: Refining the assessment of authentic leadership using exploratory bottle: Refining the assessment of authentic leadership using exploratory
structural equation modeling (ESEM). Journal of Business and Psychology, 33(5), structural equation modeling (ESEM). Journal of Business

Li, W.-D., Li, S., Fay, D., \& Frese, M. (2019). Reciprocal relationships between dispositional optimism and work experiences: A five-wave longitudinal investigation. Journal of Applied Psychology, 104(12), 1471-1486. https://doi.org/10.1037/apl0000417

Luthans, F., \& Avolio, B. J. (2003). Authentic leadership development. In K.S. Cameron, J.E. Dutton, \& R.E. Quinn (Eds.), Positive organisational scholarship (pp. 241-258). San Francisco, CA: Barrett-Koehler.

Maximo, N., Stander, M.W., \& Coxen, L. (2019). Authentic leadership and work engagement: The indirect effects of psychological safety and trust in supervisors. SA Journal of Industrial Psychology, 45(1), 1-11. https://doi.org/10.4102/sajip v45i0.1612

Mayer, R.C., \& Gavin, M.B. (2005). Trust in management and performance: Who minds the shop while the employees watch the boss? Academy of Management Journal,

Megheirkouni, M., \& Mejheirkouni, A. (2020). Leadership development trends and challenges in the twenty-first century: Rethinking the priorities. Journal of Management challenges in the twenty-first century: Rethinking the priorities. Journal of $M$ - 1 (1)
Development, 39(1), 97-124. https://doi.org/10.1108/JMD-04-2019-0114

Men, L.R., \& Stacks, D. (2014). The effects of authentic leadership on strategic internal communication and employee-organization relationships. Journal of Public Relation Research, 26(4), 301-324. https://doi.org/10.1080/1062726X.2014.908720

Muthén, L.K., \& Muthén, B.O. (1998-2019). Mplus user's guide (8th ed.). Los Angeles, CA: Muthén \& Muthén.

Neider, L.L., \& Schriesheim, C.A. (2011). The Authentic Leadership Inventory (ALI) Development and empirical tests. The Leadership Quarterly, 22(6), 1146-1164. https://doi.org/10.1016/j.leaqua.2011.09.008

Norman, S.M. (2006). The role of trust: Implication for psychological capital and authentic leadership. Unpublished doctoral thesis. Lincoln: University of Nebraska.

Norman, S.M., Avolio, B.J., \& Luthens, F. (2010). The impact of positivity and transparency on trust in leaders and their perceived effectiveness. The Leadership Quarterly, 21(3), 350-364. https://doi.org/10.1016/j.leaqua.2010.03.002

Penger, S., \& Černe, M. (2014). Authentic leadership, employees' job satisfaction, and work engagement: A hierarchical linear modelling approach. Economic Research-Ekonomska Istraživanja, 27(1), 508-526. https://doi.org/10.1080/1331677X.2014.974340

Qiu, S., Alizadeh, A., Dooley, L.M., \& Zhang, R. (2019). The effects of authentic leadership on trust in leaders, organizational citizenship behavior, and service quality in the Chinese hospitality industry. Journal of Hospitality and Tourism Management, 40, 77-87. https://doi.org/10.1016/j.jhtm.2019.06.004

Raykov, T. (2009). Evaluation of scale reliability for unidimensional measures using latent variable modeling. Measurement and Evaluation in Counseling and Development, 42(3), 223-232. https://doi.org/10.1177/0748175609344096

Richter, A., \& Näswall, K. (2019). Job insecurity and trust: Uncovering a mechanism linking job insecurity to well-being. Work \& Stress, 33(1), 22-40. https://doi.org/1 $0.1080 / 02678373.2018 .1461709$

Ruiz, M., Vives, A., Martínez-Solanas, E., Julià, M., \& Benach, J. (2017). How does informal employment impact population health? Lessons from the Chilean employment conditions survey. Safety Science, 100(A), 57-65. https://doi. org/10.1016/j.ssci.2017.02.009

Sartori, R., \& Rolandi, A. (2013). Validation study of a model for the assessment of potential in Italian Young Professionals working in medium-sized to large companies in different business sectors. Quality \& Quantity, 47, 2729-2737. https://doi.org/10.1007/s11135-012-9683-6
Schaubroeck, J.M., Peng, A.C., \& Hannah, S.T. (2013). Developing trust with peers and leaders: Impacts on organizational identification and performance during entry. Academy of Management Journal, 56(4), 1148-1168. https://doi.org/10.5465/ amj.2011.0358

Sendjaya, S., \& Pekerti, A. (2010). Servant leadership as antecedent of trust in organizations. Leadership and Organization Development Journal, 31(7), 643-663. https://doi.org/10.1108/01437731011079673

Skiba, T. \& Wildman, J.L. (2019). Uncertainty reducer, exchange deepener, or selfdetermination enhancer? Feeling trust versus feeling trusted in supervisorsubordinate relationships. Journal of Business and Psychology, 34(2), 219-235. subordinate relationships. Journal of Business
$\mathrm{https} / / /$ doi.org/10.1007/s10869-018-9537-x

Søresen, O.H. \& Hasle, P. (2009). The importance of trust in organizational change: Prerequisites for healthy organizational change. In P.O. Saksvik (Ed.), Prerequisites for healthy organizational change (pp. 10-20). Beijing: Bentham.

Stander, F.W., De Beer, L.T. \& Stander, M.W. (2015). Authentic leadership as a source of optimism, trust in the organisation and work engagement in the public health care sector. SA Journal of Human Resource Management, 13(1), 1-12. https://doi. org/10.4102/sajhrm.v13i1.675

Statistics South Africa. 2020. Quarterly labour force survey: Quarter 3, 2020. (Statistical release P0211). Retrieved from https://www.statssa.gov.za/publications/P0211/ P02113rdQuarter2020.pdf

Tourish, D., Paulsen, N., Hobman, E., \& Bordia, P. (2004). The downsides of downsizing: Communication processes and information needs in the aftermath of a workforce reduction strategy. Management Communication Quarterly, 17(4), 485-516. https://doi.org/10.1177/0893318903262241

Urbini, F., Lo Presti, A., Chirumbolo, A., \& Callea, A. (2020). Two is worse than one: The mediating role of precariousness of life in the association between qualitative job insecurity and distress among Italian temporary employees. Electronic Journal of Applied Statistical Analysis, 13(3), 634-651. https://doi.org/10.1285/ i20705948v13n3p634

Vander Elst, T., De Witte, H., \& De Cuyper, N. (2014). The Job Insecurity Scale: A psychometric evaluation across five European countries. European Journal of Work and Organizational Psychology, 23(3), 364-380. https://doi.org/10.1080/13 59432X.2012.745989

Wang, D., Kan, W., Qin, S., Zhao, C., Sun, Y., Mao, W. ... Hu, Y. (2021). How authentic leadership impacts on job insecurity: The multiple mediating role of psychological empowerment and psychological capital. Stress \& Health, 37(1), 60-71. https:// doi.org/10.1002/smi.2973

Wang, H., Sui, Y., Luthans, F., Wang, D., \& Wu, Y. (2014). Impact of authentic leadership on performance: Role of followers' positive psychological capital and relational processes. Journal of Organizational Behavior, 35(1), 5-21. https://doi. org/10.1002/job.1850

Wang, J., \& Wang, X. (2020). Structural equation modeling: Applications using Mplus (2nd ed.). Hoboken, NJ: Wiley.

Wei, F., Li, Y., Zhang, Y., \& Liu, S. (2018). The interactive effect of authentic leadership and leader competency on followers' job performance: The mediating role of work engagement. Journal of Business Ethics, 153(3), 763-773. https://doi. org/10.1007/s10551-016-3379-0

Whitener, E.M., Brodt, S.E., Korsgaard, A., \& Werner, J.M. (1998). Managers as initiators of trust: An exchange relationship framework for understanding managerial trustworthy behavior. Academy of Management Review, 23(3), 513-530. https://doi.org/10.5465/amr.1998.926624

Wong, C.A., Spence Laschinger, H.K., \& Cummings, G.G. (2010). Authentic leadership and nurses' voice behaviour and perceptions of care quality. Journal of Nursing Management, 18(8), 889-900. https://doi.org/10.1111/j.1365-2834.2010. 01113.x

Yurtkoru, E.S., Ensari, S., \& ErdilekKarabay, M. (2018). To what extent trust in leader and ethical climate affect turnover intention? A research on private and public bank employees. International Journal of Organizational Leadership, 7(1), 12-26. https://doi.org/10.33844/ijol.2018.60416

Zhang, X., \& Zhou, J. (2014). Empowering leadership, uncertainty avoidance, trust and employee creativity: Interaction effects and a mediating mechanism. Organizational Behavior and Human Decision Processes, 124(2), 150-164. https:// doi.org/10.1016/j.obhdp.2014.02.002 